\title{
Abstract
}

\section{Attachment anxiety: parenting culture, adolescence and the family film in the US}

Many authors have noted a connection between notions of childhood and understandings of parenting; however, debates have focused only on adults and their behaviour. This article interrogates the child's position in contemporary parenting culture using the Hollywood family film to explore how the cultural constructions of childhood and parenting may influence one another. The article analyses the reception of the family film of the 1990s and its representations of families and children to note a cultural response to the previous decade's "discovery" of the pre-teen demographic. This response highlighted the incompatibility of young adolescence and attachment parenting, constructing a new childhood ideal which returned the child to assumptions of vulnerability.

Keywords: Parenting culture, attachment, childhood, adolescence, Hollywood, family film

Over the past three decades, a number of authors have examined western parenting culture. Among the most influential is Sharon Hays, who identified a dominant ideology of "intensive mothering" and explained it as the result of a series of social developments beginning with "the earliest discovery of childhood innocence in Western Europe" (1996Hays, S. (1996). The cultural contradictions of motherhood. New Haven, CT: Yale University Press., p. 22). The relationship between changes in notions of childhood and changes in understandings of parenting has been noted by several other authors, who linked contemporary parenting culture with "the way society regards children. Babies and infants are seen as both intensely vulnerable and highly impressionable - above all to parental influence"

(Furedi, 2001Furedi, F. (2001). Paranoid parenting: Abandon your Anxieties and be a good parent. London: Allen Lane., p. 24). Indeed, the term parenting is seen today to be explicitly about the parent and their behaviour, with the child often understood as symbolic of a specific set of values, anxieties and social tensions related not to children but to the world of adults. As Frank Furedi wrote, "Whoever invented the term parenting was not primarily interested in the lives of children" (2001Furedi, F. (2001). Paranoid parenting: Abandon your Anxieties and be a good parent. London: Allen Lane., p. 185) the child is simply assumed to be a passive recipient, or at the very least, cooperative. 
This article interrogates the child's position in contemporary parenting culture and explores the relationship between the cultural constructions of childhood and parenting in America via a collection of film texts. Specifically, it analyses the reception of the Hollywood family film of the 1990s to note a cultural response to the previous decade's "discovery" of the pre-teen demographic. I am interested in the ways the family film represented children and their relationships with parents, and how these representations changed over time, because these constructions suggest views of childhood increasingly in line with the dominant ideologies of parenting culture at the time. Critical reviews of the films in question are of particular use in this analysis. As Barbara Klinger noted, film reviews provide important socio-cultural context by offering "insight into broader cultural attitudes" (1994Klinger, B. (1994). Melodrama and meaning: History, culture, and the films of Douglas

Sirk. Bloomington: Indiana University Press., p. 70). To this end, I examined a variety of contemporary reviews from key American publications and found explicit links between this trend of family films and the dominant ideologies of the 1990s surrounding families, parenting and childhood - what I present here is a sample of the most representative examples.

This article therefore makes three key interventions. First, it draws attention to an important aspect of parenting culture not often discussed: that the concept of childhood is as fluid as that of parenting and, therefore, constructions of a parenting culture entirely based on a very specific view of children have, at times, become misaligned with other structures of America society.

Second, the article suggests the Hollywood family film as a cultural response to this clash. Specifically responding to the emergence of the pre-teen demographic, the family film addressed and soothed anxieties over the incompatibility of young adolescence and attachment parenting, in the process constructing a new childhood ideal which returned the child to assumptions of vulnerability. Because it addressed children and parents equally, repeatedly suggesting appropriate behaviour for both parties, the family film did not simply promote a restricted vision of how to be a parent, it also suggested an ideal way to be a child.

Third, the article proposes a historical understanding of the Hollywood family film determined not by industrial context, but by culture. That is, it applies the term "family film" to mean a specific production trend of the 1990s centrally preoccupied with the child's role in the family and which negotiated social anxieties about modern parenting, especially in relation to pre-teens and attachment.

\section{Attachment in contemporary parenting culture}

The term parenting culture has been defined as "the more or less formalized rules and codes of conduct that have emerged over recent years which reflect 
[a] deterministic view of parents and define expectations about how a parent should raise their child" (Lee, 2014Lee, E. (2014). Introduction.

In J. Bristow, E. Lee, C. Faircloth, \& J. Macvarish (Eds.), Parenting culture studies(pp. 1-22). Basingstoke: Palgrave

Macmillan.10.1057/9781137304612[CrossRef], p. 10). These expectations are grounded on the belief that parents are responsible for - and can control their child's outcomes in life, including their academic, emotional and social success. These efforts might be motivated by ambition but are often the result of extreme culturally sanctioned anxiety and risk aversion (see, for example, Furedi, 2001Furedi, F. (2001). Paranoid parenting: Abandon your Anxieties and be a good parent. London: Allen Lane.).

Attachment is a central concept in this parenting climate. Originating in the studies of John Bowlby, attachment theory refers to the emotional bonding established between an infant and their primary caretakers, and the effect of this connection on the infant's development. According to attachment theorists, the consequences of insecure or inexistent attachment are severe and potentially catastrophic: apathy, failure to thrive, even death. The scientific merits of attachment theory have been questioned (Eyer, 1993Eyer, D. (1993). Mother-infant bonding: A scientific fiction. New Haven, CT: Yale University Press.) but it remains at the core of parenting practices and ideals particularly as it has been conflated with notions of risk: "(poor) attachment has become a risk factor, whilst (good) attachment has become a protective one" (Faircloth, 2014Faircloth, C. (2014). The problem of 'attachment': The 'detached' parent. In J. Bristow, E. Lee, C. Faircloth, \& J. Macvarish (Eds.), Parenting culture studies (pp. 147164). Basingstoke: Palgrave Macmillan.10.1057/9781137304612[CrossRef], p. 150).

As part of its significant impact in scientific and medical thinking, attachment theory and notions of bonding, including the fear of insecure attachment, became important concepts in culture more generally

(Warner, 2006Warner, J. (2006). Perfect madness: Motherhood in the age of anxiety. London: Vermillon., p. 94) and were, moreover, the basis of the advice given by the most popular childrearing experts of the time. One of these experts, William Sears, even coined the term "attachment parenting" to describe his methods in the first edition of The Baby Book in 1991. The term has now transcended the specific methods advocated by Sears. As author Pamela Druckerman stated, "So many of the ideas of attachment parenting are in [American] culture even if you don't believe in Dr. Sears per se.... This is a new common sense" (cited in Pickert, 2012Pickert, K. (2012). The man who remade motherhood. Retrieved fromhttp://time.com/606/the-man-whoremade-motherhood/). Indeed, Dr. Sears and his attachment philosophy have had a strong transformative impact in American parenting culture: according to Time Magazine, Sears is - not hyperbolically - "the man who remade motherhood" (Pickert, 2012Pickert, K. (2012). The man who remade 
motherhood. Retrieved fromhttp://time.com/606/the-man-who-remademotherhood/).

What needs to be noted at this point is that, while the alleged benefits of attachment last a lifetime, its articulation in parenting discourses is exclusively applied to infants and very young children. Sears, for instance, defined attachment parenting with "seven baby B's" which do not apply to a child older than two: birth bonding, breastfeeding, babywearing, bedding close to baby, belief in baby's cries, beware of baby trainers (in relation to infant schedules), and balance between baby's needs and the rest of the family (2003Sears, W., Sears, M., Sears, R., \& Sears, J. (2003). The baby book: Everything you need to know about your baby - from birth to age two (2nd ed.). Boston, MA: Little, Brown and Company., p. 6). Likewise, the advice of other experts of the 1990s was chiefly concerned with infants and very young children - Brazelton's work was based on his professional focus on infant development (1995Brazelton, T. B. (1995). Touchpoints: Your child's emotional and behavioral development. London: Penguin.), while Penelope Leach, who wrote from a slightly more inclusive perspective, still assumed a very young child (1994Leach, P. (1994). Children first: What our society must do - and is not doing - for our children today. London: Michael Joseph.).

This restricted association between parenting and babies does not just come from the scientific and medical formulations of attachment theories and infant development. It is also influenced by ideas of what the processes and goals of parenting are, as well as by a very specific understanding of childhood, based on vulnerability. But if a particular vision of childhood is the cornerstone of contemporary parenting culture, we must note that childhood, as a cultural construction, does not have a static meaning.

\section{"Discovering" the pre-teen, re-defining childhood}

Childhood has long been understood as a cultural construction (Ariès, 1965Ariès, P. (1965). Centuries of childhood: A social history of family life. New York, NY: Random House.), but while the impact of this "invention" has been acknowledged as instrumental to the shape of contemporary parenting culture, little has been said about its subsequent re-inventions and how these might have affected or been affected by cultural assumptions about parenting and families. This omission is especially striking in relation to the 1980 s and 1990s, as this was not only a moment of intensification for contemporary parenting culture, but a moment of deep transformation for the concept of childhood. I do not mean simply that this was a time in which "the belief that youngsters are inherently vulnerable and 'at risk' ... acquired the character of cultural dogma" (Furedi, 2001Furedi, F. (2001). Paranoid parenting: Abandon your Anxieties and be a good parent. London: Allen Lane., p. 16), but that it was a moment in which the structure of childhood 
itself was culturally re-worked to accommodate a new social group, the preteen.

As I have argued elsewhere, the pre-teen demographic emerged in the 1980s causing great social tension. At the heart of the debates was a cultural ambiguity about children at the cusp of puberty, who did not wholly conform to expectations of children or of adolescents. This demographic was addressed in popular culture in unprecedented ways, which challenged accepted notions of suitability as well as ideas about children's social and cultural agency. The pre-teen's emergence had measured cultural impact: the PG-13 film rating, for instance, was introduced in 1984 as a response to these controversies, clearly signposting new ideas about children and the structure of childhood as a concept (Antunes, 2017Antunes, F. (2017). Rethinking PG-13: Ratings and the boundaries of childhood and horror. Journal of Film and Video 69.1, 2743.). But though it became culturally established in the 1980s, it was in the 1990 s that the pre-teen became most visible in American society as a large number of children - the Millennials born in the "echo boom" of the 1980s collectively reached puberty.

These children may have been born in a context of childhood vulnerability, but as they reached their pre-teen years popular culture imagined and addressed them very differently. Authors studying media and consumption cultures in particular have suggested the many ways in which children's centrality in media markets is related to ideas of citizenship, as well as the cultural, social and economic power of younger demographics (e.g., Banet-

Weiser, 2007Banet-Weiser, S. (2007). Kids rule! Nickelodeon and consumer citizenship. London: Duke University Press.10.1215/9780822390299[CrossRef]; Kinder, 1991Kinder, M. (1991). Playing with power in movies, television, and video games: From Muppet Babies to Teenage Mutant Ninja Turtles. Berkeley: University of California Press.; Seiter, 1993Seiter, E. (1993). Sold separately: Children and parents in consumer culture. New Brunswick, NJ: Rutgers University Press.). These relationships were, moreover, an important part of marketing strategies of the time. The media marketing manual Kidfluence, for instance, noted how "one of the most notable [changes in the 1990s was] the shift in the balance of power," meaning that parents no longer made all the decisions and instead consulted their children on a variety of family purchases, from breakfast cereal to cars and holidays (Sutherland \& Thompson, 2003Sutherland, A., \& Thompson, B. (2003). Kidfluence: The marketer's guide to understanding and reaching generation Y-kids, tweens, and teens. New York, NY: McGrawHill., p. 17).

This definition of "children" did not subscribe to the concepts of extreme vulnerability used in parenting language, even as it stemmed, at least in part, from the principles of contemporary parenting culture: the authors of Kidfluence suggest children's consumer power as an outcome of new 
parenting practices, which "promote the concept that all family members are equally valued and given consideration regardless of age; a concept that is part of permissive parenting"(Sutherland \& Thompson, 2003Sutherland, A., \& Thompson, B. (2003). Kidfluence: The marketer's guide to understanding and reaching generation Y-kids, tweens, and teens. New York, NY: McGrawHill., p. 17). This quotation begins to suggest the relationship between cultural assumptions of parenting and of childhood, but it specifically points out something not often mentioned in parenting literature: that parenting is a process that lasts well beyond babyhood and therefore one that affects and is affected by older children too.

In the context of parenting culture, the pre-teen thus becomes a point of tension. Although they are in some ways children, pre-teens do not fit the assumption of a vulnerable, unconditionally cooperative infant; and because they are the target of popular messages about consumer power, social agency and cultural presence, the methods of intensive parenting may cause friction between parent and child. In the context of the 1990s specifically, this clash between adolescent identity and attachment-focused parenting is further complicated by the novelty of the pre-teen as a concept - families parenting Millennial children were not only riding the first wave of attachment parenting but also contending with the first historical batch of pre-teens.

\section{Identifying the family film}

These tensions are strongly circulated in popular culture of the period, particularly in the cinema, which overflowed with portrayals of parents and their children. This sort of representation of the family has often been analysed as a window into cultural discourses and social anxieties. Williams (1996Williams, T. (1996). Hearths of darkness: The family in the American horror film. London: Associated University Presses.), for example, has argued that the family has a fundamental presence in the structure of Hollywood horror, signalling not only normalcy but a dangerous space in which the most unsettling fears are enacted. More commonly, however, the family as object of study has been dismembered into the separate issues of motherhood and fatherhood, often read in terms of gender and identity (e.g.,

Bruzzi, 2005Bruzzi, S. (2005). Bringing up daddy: Fatherhood and masculinity in post-war Hollywood. London: BFI Publishing.; Chopra-Gant, 2006ChopraGant, M. (2006). Hollywood genres and postwar America: Masculinity, family and nation in popular movies and film noir. London: I.B. Tauris.;

Fischer, 1996Fischer, L. (1996). Cinematernity: Film, motherhood, genre. Princeton, NJ: Princeton University Press.10.1515/9781400851591[CrossRef]). In these analyses, parenting is addressed as an ideological aid to other constructions, often about what it means to be a man or a woman. For instance, Hannah Hamad's work on Hollywood fathers concludes that "fatherhood has been consistently deployed in contemporary popular cinema as the paradigmatic formation of masculinity 
for postfeminist culture" (2014Hamad, H. (2014). Postfeminism and paternity in contemporary US film: Framing fatherhood. New York, NY: Routledge., p. 136).

Part of my aim in this article is to demonstrate the value of reading parenting as a practical representation of itself, from a perspective that is not simply adult-centric but which examines parenting as a relationship between parent and child (as, indeed, modern parenting regards itself). This approach is particularly valuable when applied to the cluster of family films of the 1990s and early 2000s, because their specific target of parents and children - and the privileged way in which their relationship is portrayed on screen - is instrumental in creating their ideology.

As an illustration, take Jyotsna Kapur's work on the transformation of childhood, which argues that the blurring of boundaries between children and adults during this period is a result of capitalism. Kapur suggests that films like Home Alone or Matilda suggest a temporary solution to this "threat ... to the hierarchy of children and adults" by reinstating "the old-fashioned child" at the end of their narratives (2005Kapur, J. (2005). Coining for capital: Movies, marketing, and the transformation of childhood. New Brunswick, NJ: Rutgers University Press., p. 126). Though this reading is parallel in some ways to what I offer here, the use of a Marxist structure subverts what has become a fundamental characteristic of attachment parenting (and, as a result, of currents views of childhood): the rejection of strict power hierarchies between children and their parents. This nuance is important not just in understanding the centrality of attachment principles in the 1990s, but also in clarifying that these films do not reinstate any previous model of childhood; they construct a new one.

As these approaches suggest, "the family," "the parent" and "the child" have rarely been read as simply the family, the parent and the child. The same flexibility applies to the family film itself, which tends to be interpreted not as a genre or a textual identity, but as an industrial and commercial form. It is, as Noel Brown puts it, "the clearest manifestation of Hollywood cinema's ongoing pursuit of mass acceptance" (2012Brown, N. (2012). The Hollywood family film: A history, from Shirley Temple to Harry Potter. London: I.B. Tauris., p. 14). This definition stems from a very fluid understanding of what the word "family" might mean in this context: for Kramer, family audiences include parents and children, but also teenagers and young adults (1998Kramer, P. (1998). Would you take your child to see this film? The cultural and social work of the family-adventure movie.

In M. Smith \& S. Neale (Eds.), Contemporary Hollywood cinema (pp. 294311). London: Routledge.), while Brown explicitly reads the family audience as "symbolic" (2012Brown, N. (2012). The Hollywood family film: A history, from Shirley Temple to Harry Potter. London: I.B. Tauris., p. 2). This figurative understanding of family audiences is useful to analyse Hollywood's industrial 
practices but it proves inadequate to understand the trend I target here, which took "family audiences" literally.

This problem is highlighted in the work of Robert C. Allen. Writing with an economic focus, Allen uses the family film as a signifier of Hollywood's new industrial climate, in which ancillary markets and new technologies expanded not just the scope of the industry but also its sense of audiences. Thus Allen described the family film as deliberately broad, with "moral and, by extension, ideological ambivalence" (p. 125), in line with the overall industrial view that the 1990s were a time in which "it became less and less [commercially advantageous] to [be aligned] with any particular figuration of the family or any unequivocal set of 'family values'" (1999Allen, R. C. (1999). Home alone together: Hollywood and the 'family film'.

In M. Stokes \& R. Maltby (Eds.), Identifying Hollywood's audiences: Cultural identity and the movies (pp. 109-131). London: British Film Institute., p. 116). However, the author also briefly acknowledged that "such family films as Home Alone, Mrs. Doubtfire, Jumanji, Matilda, Addams Family, or Problem Child" operated differently (1999Allen, R. C. (1999). Home alone together: Hollywood and the 'family film'. In M. Stokes \& R. Maltby (Eds.), Identifying Hollywood's audiences: Cultural identity and the movies (pp. 109131). London: British Film Institute., p. 125).

Allen never specified the difference, nor did he attempt to explain it, perhaps because to do so from a strictly industrial angle would be quite difficult. Indeed, these films challenge Allen's assumptions of industrial and ideological ambivalence, not only because they target a literal family audience but also because they promote a very specific set of family values and parenting culture. This becomes even more apparent in the films' critical reception, where each of these titles was interpreted as sincere (if sentimental) affirmations of family values and of the importance of children.

Matilda, for instance, was seen to have "a poignant undercurrent [about children and family] that should not be ignored or underestimated" (Leydon, 1996Leydon, J. (1996, August 5). Review: 'Matilda'. Retrieved fromhttp://variety.com/1996/film/reviews/matilda-2-1200446502/), while Mrs. Doubtfire was labelled a collection of "pseudo-public-service announcements" about families and divorce (Hillard, 1993Hillard, D. (1993, November 28). Review: 'Mrs. Doubtfire'. Retrieved fromhttp://variety.com/1993/film/reviews/mrs-doubtfire-2-1200434086/). Critics also highlighted the ways Problem Child is a very different exception. It was the only feature mentioned by Allen as different to be read as explicitly ambiguous about the value of the family; it was also critically panned, in great part because of its depiction of childhood and family. "This is one brat," wrote one of several exasperated reviewers, "and one bratty movie, that's nearly impossible to tolerate, much less like" (Hinson, 1991bHinson, H. (1991b, July 5). Problem Child 2 (PG-13). Retrieved 
fromhttp://www.washingtonpost.com/wp-

srv/style/longterm/movies/videos/problemchild2pg13hinson_a0a6c7.htm).

The socio-cultural context then clarifies what made this small cluster of 1990s' films different from the other "family films" of the era: they responded to America's preoccupation with the family and affirmed dominant cultural preferences for a specific view of children. The exact focus of these concerns shifted slightly over time, forming two distinct cycles - the first themed around adolescence (early 1990s), the second around the work/life balance (late 1990s-early 2000s) - but the overall ideology of the family film was firmly grounded in the ideals of attachment parenting culture. Specifically, the family film worked from three assumptions about families and childhood: that families are a natural part of a fulfilled life; that families are not defined by marriage but by a parent's relationship to their child; and that children are innocent and vulnerable.

This guiding ideology was not only a part of the films' narratives, it was also an implied industrial preoccupation, and critically recognised in the conventions of the period. Take for instance Spielberg's Hook. Even though Spielberg's fame and the film's source material have strong connotations with childhood innocence, Hook is more parenting-oriented than it is nostalgic for childhood. As one reviewer noted:

The movie isn't simply about the happiness of childhood; it's about the pleasures of growing up too. When Peter finally remembers his Happy Thought, it's not a childhood memory [but] an adult epiphany. ... Peter recalls the birth of his son, and in doing so, he remembers why he chose to grow up and abandon Neverland forever - in the first place: He wanted to be a father. (Hinson, 1991aHinson, H. (1991a, December 11). Hook. Retrieved fromhttp://www.washingtonpost.com/wpsrv/style/longterm/movies/videos/hookpghinson_a0a725.htm)

In other words, Hook transformed Peter Pan's fantasy of eternal childhood into a fantasy of parenthood. Other films presented similar ideals. In the case of Mrs. Doubtfire, this vision was deliberately constructed during the editing process, which removed scenes that portrayed the hurt, anger and resentment that may come with divorce, especially where children are concerned (Keys, 2016Keys, M. (2016). Lost footage: Heartbreaking "Mrs. Doubtfire" deleted scenes. Retrieved fromhttps://www.youtube.com/watch?v=-8YuV2wJyM). In one of these deleted scenes, the family's eldest daughter asks, "why can't you and Mom pretend to be happy ... then we'd still be a family;" in another, Daniel accuses his ex-wife of trying to "destroy the fact that we're a family," before he is interrupted by the children who, witnessing the fight, declare to "hate [them] both."

These scenes have a much more serious tone than the rest of the film, but their main violation of the family film ethos is that they assumed the family to 
be defined by marriage, moreover suggesting the taboo notion that parental actions may negatively affect the children's love for them. The final cut instead presents divorce as a painful but ultimately positive change for the family in the story, and spells out the message at the end through the character of Mrs. Doubtfire: "Just because they don't love each other anymore doesn't mean that they don't love you. There are all sorts of different families ... But if there's love ... you'll have a family in your heart, forever."

These assumptions of family were so strongly associated with the family film that reviewers often noted when a film deviated from expectations. The Parent Trap, for example, proved challenging to critics who felt that "contempo audiences may have trouble accepting a few of the plot elements carried over from the original" (Leydon, 1998Leydon, J. (1998, July 27). Review: 'The Parent Trap'. Retrieved fromhttp://variety.com/1998/film/reviews/the-parenttrap-3-1200454277/), specifically "that divorced parents as loving as [these] would divide up their twins at birth and agree never to see one of them again" (Stein, 1998Stein, R. (1998, July 29). Family fixer-upper/“Parent Trap" gets a coat of sugar in entertainment remake. Retrieved

fromhttp://www.sfgate.com/movies/article/Family-Fixer-Upper-Parent-Trapgets-a-coat-of-2999456.php). Though the plot gimmick was noted, it serves in the film to underline an ideological point, namely that this family was dysfunctional and became whole only when each child forms a relationship with the missing parent.

This understanding of the family film applies only to a limited group of titles, leaving out much of what other authors have called "family film." However, this limitation is a strength: it highlights the family film's position as a cultural product of its time, revealing the centrality of the family in American society but also, as the next sections will show, mapping the changes in how the concept was articulated, especially in relation to the child's role in the family.

\section{Challenging adolescence}

The pre-teen is central in the family film, especially in the films of the first cycle, where they invariably drive the narrative (and this narrative is often about their pre-adolescence). This is explicit in the Home Alone series and in The Parent Trap but also in films like Jumanji, in which the entire "family" is composed of pre-teens or Mrs. Doubtfire, which favours Daniel's relationship with his young adolescent son over his younger and older daughters. This was not the case in the 1980s where, with the exception of E.T., the few productions concerned with the family unit tended to predominantly feature older teenagers (as in the Back to the Futurefilms). The use of pre-teen actors has some advantages, such as the possibility for more nuanced performances while still capitalising on child-like looks, but it also prompted the family film to address the effects of puberty on family dynamics - and, importantly, to offer a "solution" for it. 
As others have argued, film and other media circulate contemporary expectations of families, promoting a specific set of parental behaviours and attitudes towards parenthood (Douglas \& Michaels, 2004Douglas, S. J., \& Michaels, M. W. (2004). The mommy myth: The idealization of motherhood and how it has undermined women. New York: Free Press.). The family film similarly circulated the expectations of contemporary parenting culture, but in articulating them in relation to adolescence, these expectations were directed at both adults and children. Indeed, the vision of family life that was promoted in the family film was heavily reliant on specific expectations of children and their behaviour. This was not related to discipline (on the contrary, "bad" behaviour was often rewarded) but rather with compliance to the rules of parenting culture: vulnerability, innocence and unwavering attachment.

Home Alone is a clear example. Academically, it has been interpreted as a symbol of modern parenting and its flaws, namely the "neglect" suffered by children. According to Joe Kincheloe, the first two Home Alone films "work hard to deny it, [but are] about a child unwanted by his family - as are many other films of the 1980s and 1990s" (1998Kincheloe, J. L. (1998). The new childhood: Home alone as a way of life. In H. Jenkins (Ed.), The Children's culture reader(pp. 159-177). New York: New York University Press., p. 161). For Kincheloe, the films' unspoken theme is thus "the hurt and pain that accompany children and their families in postmodern America"

(1998Kincheloe, J. L. (1998). The new childhood: Home alone as a way of life. In H. Jenkins (Ed.), The Children's culture reader(pp. 159-177). New York: New York University Press., p. 159). Similarly, Allen's reading of Home Alone is that

Kevin ... has learned to be both mother and father to himself. Despite the film's Capraesque allusions and the restoration of the nuclear family in its final scene, these ideological alliances are undermined by the lesson Kevin seems to have learned: if being a child in a postmodern family means being alone ... then the appropriate coping strategy is to reconstruct the nuclear family within yourself. (1999Allen, R. C. (1999). Home alone together: Hollywood and the 'family film'. In M. Stokes \& R. Maltby (Eds.), Identifying Hollywood's audiences: Cultural identity and the movies (pp. 109-131). London: British Film Institute., p. 126)

Both readings come from the assumptions that Kevin is a child and that children are vulnerable; that his independence is in some way undesirable. Kevin is, of course, a child, but he is also a pre-teen, meaning that when he learns to look after himself in the film, he might not be creating a surrogate family within himself as much as simply expressing some adolescent independence. And this is generally how reviewers read it: the film "became a hit by speaking to secret wishes any child could understand: the desire for independence, the novelty of feeling empowered, the triumph of defending one's castle ... [T] hese messages [come through] loud and clear" (Maslin, 1992Maslin, J. (1992). Review/Film; Alone again: Holiday mischief in 
manhattan. Retrieved

fromhttp://www.nytimes.com/movie/review?res=9E0CEED71030F933A15752 C1A964958260).

The contrast between these opposing academic (childhood vulnerability) and critical views (recognising the pre-teen as a different kind of child) is addressed and resolved in Home Alone's narrative. Through the use of dual address, the film follows both Kevin and his mother, Kate, in their journeys back to the family. Kate's arc is emotional and led by guilt. "I'm a bad mother," she reflects, expressing, as one critic put it, "maternal devotion bordering on martyrdom" (Maslin, 1990Maslin, J. (1990). Review/Film; Holiday black comedy for modern children. Retrieved fromhttp://www.nytimes.com/movie/review?res=9C0CE6D8143DF935A25752 C1A966958260). Through her physical journey back to Kevin, Kate atones for leaving him alone but also for her breach of contemporary parenting's rules of attachment. When Kevin forgives her at the end, this is not just about the physical separation but also the emotional disconnect we see in the film's first act, when Kate and Kevin are not securely "attached."

But Kevin was also part of the problem. As one critic noted, "the point of 'Home Alone' is that Kevin, through his experiences, learns a little bit about self-reliance and appreciation for his family" (Hinson, 1990Hinson, H. (1990, November 16). Home Alone. Retrieved fromhttp://www.washingtonpost.com/wpsrv/style/longterm/movies/videos/homealonepghinson_a0a9b9.htm). His adventures in the film are as much about redemption as Kate's journey back home, reminding him not just of the work his mother does to look after him (he goes shopping, cooks, does the laundry), but also of the invaluable emotional connection between them. In the process, Kevin's adolescent rebellion is redirected, no longer used to attack his family but to defend it; from "I don't want any family. Families suck! ... I don't want to see you again for the rest of my whole life" to "This is extremely important. ... instead of presents this year, I just want my family back."

In this way, Home Alone identifies Kevin's young adolescent identity while also affirming his need to still be parented. Attachment during puberty is thus represented as not only possible but inevitable, an ideal sought by the child as diligently as by the parent. Films like Home Alone or Jumanji, in which Alan can only restore his family after he has learned to be grateful to his father, circulate the promises of attachment alongside its ideals: in the words of Dr. Sears, "the connected child desires to please [and is] easier to discipline" (2003Sears, W., Sears, M., Sears, R., \& Sears, J. (2003). The baby book: Everything you need to know about your baby - from birth to age two (2nd ed.). Boston, MA: Little, Brown and Company., p. 19), even when going through puberty. 
This anxiety over adolescence (and the representation of its inevitable conquest) suggests a wider process of negotiation between two emergent cultural notions: on the one hand, attachment ideology and a view of children as vulnerable; on the other, social acceptance of the pre-teen as a different sort of child. The family film therefore presents an important cultural struggle to continue parenting beyond childhood, a desire borne out of attachment parenting ideals but curtailed by the emergence of the pre-teen demographic. As verbalised in Hook:

Your children love you. They want to play with you. How long do you think that lasts? Soon Jack may not want you to come to his games. We have a few special years with our children, when they're the ones who want us around. After that you're going to be running off to them for a bit of attention. So fast, Peter - it's a few years, then it's over.

Though the above quote is directed at parents, as the first cycle progressed, the conflict became articulated primarily through - and directed at - children, in the repetition of child role models who remain vulnerable into their adolescence. These representations also guided parents in their expectations, both of their own child's behaviour and of their parenting relationship.

Casper is a good example here. The film uses gothic imagery to explore parental confusion about raising the new pre-teen version of their child: the film's Manor stands for the domestic space and the family and the ghosts that haunt it are a literal embodiment of fears of transition - Casper is a horror story for the family about to face adolescence. The film uses death as a symbol for the end of childhood, and ghostliness for the transition period of pre-adolescence, but these symbols are not exclusively applied to children in the Harvey family, it's not Kat who dies and becomes a ghost but her father. In this instance, the end of Kat's childhood causes Dr. Harvey to let go of his attachment to her, regressing to a time before family and responsibility.

Dr. Harvey's anxieties about parenting a pre-teen are central to the narrative and to director Brad Silberling's vision for the film. In the film's commentary, Silberling reflected on Dr. Harvey's fear of "not being quite up to speed on what it is to raise a daughter" and his tendency to "panic, as any parent would, about not having the skills to parenting, about not knowing how to raise a girl, being a guy himself" (2008Silberling, B. (2008) Casper DVD commentary. UK: Universal Pictures.). Although Silberling explicitly pointed out the gender differences between Dr. Harvey and his daughter, what the film actually highlights is the mismatch between his parenting and Kat's reality: Dr. Harvey is confused about which words to use (Kat wants to "hang" with her friends, not "play"), does not seem to be in tune with his daughter's preoccupations (looking "date-nice," not "cute"), and when he displays his affection by kissing her on the cheek, Kat's response is "I hope no one saw that." 
In spite of this, Casper makes it obvious that Kat still loves and needs her father. His abandonment is devastating to her, and the film's climax is driven by her hurt at having been forgotten. Her tearful demonstration of filial love works in more ways than one to accomplish the goal of "emotional healing" (Silberling, 2008Silberling, B. (2008) Casper DVD commentary. UK: Universal Pictures.). As Dr. Harvey remembers his parental duty, the film guides the audience in a similar direction, emphasising the pre-teen's vulnerability and the strength of a child's attachment, in much the same way as baby-focused parenting literature. The film's message is clear: the pre-teen years are not a threat to the attached family but may actually be a moment when the child needs their parents the most.

Thus, in its first cycle, the family film distinctly articulated parenting culture in relation to changes in childhood. Its ideology embraced and promoted contemporary parenting ideals, but the dual address of its narratives allowed for a unique emphasis on expectations of children and their behaviour. As a result, the family film's representations of the young adolescent shaped the pre-teen years to conform to contemporary parenting culture: vulnerability and attachment are emphasised, and traits like independence and rebellion redirected to enhance rather than threaten the family's bond.

\section{Young and attached}

As the family film entered its second cycle in the mid-1990s, narrative focus shifted from adolescence to the impact of careers and work on family life. As a result, both children and parents were represented differently: parents became more central and children noticeably younger and more innocent. This shift suggests a new set of concerns within parenting culture but also new attitudes towards children and their position in the family.

The change is illustrated in the development of the Home Alone series. The third instalment was released in 1997, five years after Kevin's second adventure. It follows a different child, Alex, who is left alone under very different circumstances: he is ill with chickenpox and his mother cannot find last-minute childcare. Although Alex is left alone several times over the course of the film, it is only for a couple of hours and a neighbour is on call should he need anything. The film goes to great lengths to detail the (relative) plausibility of its set-up and avoid connotations with child neglect by repeatedly stressing the guilt felt by Alex's parents about the situation. Kate McCallister may have been able to forget about Kevin, but Alex's mother cannot keep her son out of her mind - not only has she given him a beeper, she will also "call every half an hour, ... go online and keep the connection open all day."

In interview, writer John Hughes stressed the differences between this film and the first two in the series, reassuring audiences that "no one will go further than down the block" (cited in Marilyn Beck, 1996Marilyn Beck, S. J. S. (1996, 
December 5). John Hughes has new kid for new 'Home Alone'. Manila standard. Retrieved

fromhttps://news. google.com/newspapers? $\mathrm{nid}=1370 \&$ dat $=19961205 \& \mathrm{id}=4 \mathrm{p} 4 \mathrm{~V}$ AAAAIBAJ\&sjid=zgoEAAAAIBAJ\&pg=6146,737721\&hl=en). Home Alone 3 had, as Hughes put it, "a more realistic edge" (1996Marilyn Beck, S. J. S. (1996, December 5). John Hughes has new kid for new 'Home Alone'. Manila standard. Retrieved fromhttps://news.google.com/newspapers? $\mathrm{nid}=1370 \&$ dat $=19961205 \& \mathrm{id}=4 \mathrm{p} 4 \mathrm{~V}$ AAAAIBAJ\&sjid=zgoEAAAAIBAJ\&pg $=6146,737721 \& \mathrm{hl}=$ en) than the previous films in the series because it did not star an aspirational family: "We'll be dealing with the reality of the American family of today ... the parents worrying about coping with the needs of the kids, about their jobs, child care" (1996Marilyn Beck, S. J. S. (1996, December 5). John Hughes has new kid for new 'Home Alone'. Manila standard. Retrieved fromhttps://news.google.com/newspapers? nid=1370\&dat=19961205\&id=4p4V AAAAIBAJ\&sjid=zgoEAAAAIBAJ\&pg=6146,737721\&hl=en). The film can only be considered realistic in Hollywood terms, yet its representations of family life do seem to reflect the values of contemporary parenting culture more closely than the first two Home Alone, starting with the swift rejection of the notion that any parent could forget their child or leave them home alone willingly.

Karen Pruitt is, perhaps unsurprisingly, a much more intensive mother than Kate McCallister ever was - and Alex a much more devoted son than Kevin. $\mathrm{He}$ is never rude, insolent or even remotely demanding, and his attachment is so unconditional he never even gets upset when he is left alone. "It's okay," he says to his mother with a hug. "It's not you. It's the times." Dr. Sears' advice in The Baby Book comes to mind here: "parenting is a guilt-ridden profession. Love for your baby makes you vulnerable to feeling you are not doing enough," but "attached children are resilient, and this helps take the pressure off parents" (p. 15). This was the unspoken motto of the family film's second cycle. The child was transformed from a potential obstacle to family attachment into a resilient, steadfast champion of attachment.

The benefits of such soothing representations are obvious when parental anxieties over the work/life balance are considered; however, the happy resolution of scenarios like those of Home Alone 3 requires the child to be at once vulnerable and immediately understanding of parental perspectives, leaving little space for character growth. Alex, like all children in the family film's second cycle, has no narrative progression - he is already perfect when the film begins, because he embodies the childhood ideal. The problem with this kind of symbolic presence is that it severely limits exploration of the child's feelings about his family situation, which had been a characteristic of the family film previously.

The Parent Trap provides a good example here. Contemporary critics read it as a morality tale about parenting and careers; it was seen as a story where "each parent has worked hard to achieve professional success," and therefore 
one which presented "an inevitable question: Just how much quality time has each girl really had with Mom or Dad?" (Leydon, 1998Leydon, J. (1998, July 27). Review: 'The Parent Trap'. Retrieved fromhttp://variety.com/1998/film/reviews/the-parent-trap-3-1200454277/). As in other films of the period, however, the implications of this question were not explored from the child's perspective but served as commentary on parenting and modern life. As Ebert noted, "the real story involves the parents" (1998Ebert, R. (1998, July 29). The Parent Trap. Retrieved fromhttp://www.rogerebert.com/reviews/the-parent-trap-1998). Indeed, the film does very little to explore the psyche of the girls, who seem to have no hurt feelings about having been abandoned by one of their parents following divorce. Nor was this seen to be an important detail for reviewers, who instead focused on the moments where the girls expressed love and understanding towards their parents. One critic, for instance, thought that the highlight of Lindsay Lohan's performance was her expression of "each twin's efforts to hide the joy she feels when finally meeting the parent she's never known" (Leydon, 1998Leydon, J. (1998, July 27). Review: 'The Parent Trap'. Retrieved fromhttp://variety.com/1998/film/reviews/the-parent-trap-31200454277/).

Another film of this period, Jingle All the Way, presents an even more parentcentric version of a similar scenario, in which the child acts as little more than a token character. As one reviewer noted, this film had a "valuable message" about "the quality of family relationships and the need to make time for the kids" (Guthmann, 1996Guthmann, E. (1996, November 22). Film review Arnie doesn't ring any comedy bells/Hokey holiday film doesn't quite 'Jingle'. Retrieved fromhttp://www.sfgate.com/movies/article/FILM-REVIEW-ArnieDoesn-t-Ring-Any-Comedy-2958581.php) but no similar significance for the children in the audience. On the contrary, it was seen as "an erratic comedy that will frustrate children" (Levy, 1996Levy, E. (1996, November 30). Review: 'Jingle All the Way'. Retrieved fromhttp://variety.com/1996/film/reviews/jingleall-the-way-2-1117437028/). Levy explicitly pointed out the shift in his review: "Laying the same guilt on parents for neglecting their children as did 'Home Alone,' 'Jingle All the Way' reverses the 1990 blockbuster's p.o.v. Instead of focusing on the children, [it] centers on the desperate efforts of a workaholic father" (1996Levy, E. (1996, November 30). Review: 'Jingle All the Way'. Retrieved fromhttp://variety.com/1996/film/reviews/jingle-all-the-way-2$1117437028 /)$.

In this new shape, the family film moved closer to parenting culture as we know it today: children, though central, were effectively sidelined in the action. They may have some personality and a small degree of agency, but never mature into their own identity or independence; on the contrary, the child's innermost desire in the family film is simply to remain a child - vulnerable but protected in the safety of the nuclear family. Often, children were represented as incredibly intelligent and wise beyond their years, but this combination of precociousness and vulnerability is no contradiction. Children like Alex 
in Home Alone or Hallie and Annie in The Parent Trap may have the plotting skills of an adult, they do not break any expectations of childhood, such as sexual innocence or a preoccupation with family attachment.

In the few instances where a child's actions might be seen to break away from expectations, in fact, the problem was circumvented with other strategies of representation: the naughtier the child, the younger they were portrayed. Home Alone is again a good example. The first two films, which feature a pre-teen, were often accused of portraying a borderline sadistic child; however, critics also noted how the film's tone was shaped by its familyfriendly ideology: "If you took Home Alone and removed any justification for the kid's demonic booby traps (he was trying to protect his castle, remember?), you'd have the Problem Child movies"

(Gleiberman, 1991Gleiberman, O. (1991, July 19). Problem Child 2. Retrieved fromhttp://www.ew.com/article/1991/07/19/problem-child-2) - Problem Child being a comedy series about an evil young child who does not love or respect his adoptive family. And, incidentally, Home Alone 3 features a child noticeably younger than Kevin, with no traces of adolescent rebellion.

Another film about an unruly child, Dennis the Menace, used a similar strategy to deflect criticism of sadistic or inappropriate behaviour. As Ebert commented in his review:

[T] he fatal flaw in the 'Dennis the Menace' TV series was that the Dennis character was old enough to know better. That is not the case with the [movie,] in which the little monster [is seven]. Dennis' tender years allow him the luxury of innocence ... Dennis is not malevolent, just very, very bad at decision-making. (1993Ebert, R. (1993). Dennis the Menace. Retrieved fromhttp://www.rogerebert.com/reviews/dennis-the-menace-1993)

Ageing Dennis down, like Alex for Home Alone 3, is a choice that ensures the child conforms to notions of innocence and vulnerability from the start - rather than challenge them first, before being re-directed to the appropriate model, as in the films of the first cycle.

Here, the family film seems to be negotiating a shift in cultural understandings of parenting and families. In the first cycle, family harmony was presented as the result of mutual efforts between children and parents, suggesting the child as an active participant but also as a potential cause of family dysfunction: if the adults may neglect to make the child a priority, the child may also neglect to appreciate their parents. There are hints of attachment ideology in films like Home Alone but they are mixed with traces of previous childrearing philosophies, including the notions of respect towards the authority of parents, a sense of children being capable of doing bad things and the need to hold them accountable for their actions.

These ideas are noticeably diluted in the films of the second cycle, indicating a solidification of ideals of attachment and childhood innocence in modern 
parenting culture. There was no suggestion of the child posing a real challenge; the trouble they caused was strictly because of good intentions (citizenship, attachment, vulnerability). Instead, the child is represented as a source of joy as well as motivation for self-improvement for the parents. These points are especially enforced in the second half of this cycle, in the early 2000s, which more heavily focuses on men and the rediscovery of fatherhood: Daddy Day Care, Cheaper by the Dozen and their sequels, as well as Finding Nemo, The Pacifier and others, which presented fatherhood as a path to emotional maturity (and, as Hamad (2014Hamad, H. (2014). Postfeminism and paternity in contemporary US film: Framing fatherhood. New York, NY: Routledge.) proposes, ideal masculinity). From the mid-1990s onward, therefore, the family film's barometer of parenting anxieties had clearly shifted away from a focus on individual parentchild relationships, to the external and fundamental clashes between attachment parenting and contemporary social structures, namely the current model in which many women work outside of the home.

\section{Conclusion}

If the family film trend is understood as a chart of the establishment of parenting culture in America, as I have suggested here, then its representation of children and their role within the family is crucial - it mapped a key change in understandings of childhood. First, it introduced the notion of children as vulnerable; then, children as resilient and understanding. Most importantly, however, the family film reveals the ways in which the concept of the child has been culturally reworked by an attachment-focused parenting culture.

Indeed, if the family film trend parallels the establishment of modern parenting ideals, it is impossible not to notice that it begins as an attempt to resolve the challenge posed by emerging re-definitions of childhood, in particular the association between the pre-teen demographic and an active participation in the family, society and culture more generally. And it is also hard not to notice that this association was eroded as the trend progressed, gradually favouring a representation of children as entirely vulnerable and, often, passive. This transformation is key. It not only signposts a historical moment of tension between the concepts of childhood and parenting, but also highlights a synergy between the two more complex than is usually assumed. What the family film suggests is a deliberate (though not necessarily conscious) reconstruction of childhood to contain the pre-teen demographic within the boundaries and ideals of attachment parenting.

This containment was primarily achieved through the repetition of vulnerability. This was usually articulated in relation to the child's need for their parents' love and protection, but the child characters themselves also became progressively more innocent (in actions and motives). Simultaneously, children in the family film became noticeably younger: the pre-teen may have 
ruled the first cycle, but children aged in the single digits are more common in the second, while the third is almost entirely dominated by young children and babies. This ageing-down process implies an end of anxieties over adolescence, but it also pushed the older child or young adolescent away from the centre of meaningful agency.

At the same time, the family film's development echoes the intensification of contemporary parenting culture as described by authors like Sharon Hays and others. But while these writers have noted higher expectations of parents, the corresponding focus on children has been sorely neglected. As audiences of film - and as citizens and cultural agents - children are just as much the receivers of messages about family and parenting culture. Just as parents receive messages of attachment, children are presented with a range of appropriate responses to their parents and with an ideology about themselves that is based on vulnerability and unquestioning filial devotion.

These messages targeted at children are emphatic reminders of the levels of anxiety inherent in modern parenting culture. In the family film specifically, the happy endings and dual address strategies effectively established two levels of soothing for parents: the first, articulated through the adult characters, soothed anxieties over parenting challenges and the conflicts between attachment and modern life; the second, articulated through the child characters, soothed anxieties over uncertain attachment by presenting an educational image of the child as understanding, loving and responsive before, during and after adolescence.

As the family film trend illustrated, adolescence did not remain a source of tension for a long time; today, it is even common sense that children need and want their parents to be involved in their lives well beyond childhood and even beyond adolescence. But the brevity of this cultural disruption should not be a reason for its dismissal; rather, it should compel further reflection on our assumptions about children and the family. The family film did not simply reflect social anxieties over adolescence; it negotiated the synergy between notions of childhood and parenting in relation to dominant ideologies - not a unidirectional model of influence but a much more complex relationship, in which childhood and parenting cultures continuously shape each other.

\section{References}

Allen, R. C. (1999). Home alone together: Hollywood and the 'family film'. In M. Stokes \& R. Maltby (Eds.), Identifying Hollywood's audiences: Cultural identity and the movies (pp. 109-131). London: British Film Institute. 
Antunes, F. (2017). Rethinking PG-13: Ratings and the boundaries of childhood and horror. Journal of Film and Video 69.1, 27-43.

Ariès, P. (1965). Centuries of childhood: A social history of family life. New York, NY: Random House.

Banet-Weiser, S. (2007). Kids rule! Nickelodeon and consumer citizenship. London: Duke University Press.

Brazelton, T. B. (1995). Touchpoints: Your child's emotional and behavioral development. London: Penguin.

Brown, N. (2012). The Hollywood family film: A history, from Shirley Temple to Harry Potter. London: I.B. Tauris.

Bruzzi, S. (2005). Bringing up daddy: Fatherhood and masculinity in post-war Hollywood. London: BFI Publishing.

Chopra-Gant, M. (2006). Hollywood genres and postwar America: Masculinity, family and nation in popular movies and film noir. London: I.B. Tauris.

Douglas, S. J., \& Michaels, M. W. (2004). The mommy myth: The idealization of motherhood and how it has undermined women. New York: Free Press.

Ebert, R. (1993). Dennis the Menace. Retrieved from http://www.rogerebert.com/reviews/dennisthe-menace-1993

Ebert, R. (1998, July 29). The Parent Trap. Retrieved from http://www.rogerebert.com/reviews/the-parent-trap-1998

Eyer, D. (1993). Mother-infant bonding: A scientific fiction. New Haven, CT: Yale University Press.

Faircloth, C. (2014). The problem of 'attachment': The 'detached' parent. In J. Bristow, E. Lee, C. Faircloth, \& J. Macvarish (Eds.), Parenting culture studies (pp. 147164). Basingstoke: Palgrave Macmillan.10.1057/9781137304612[CrossRef]

Fischer, L. (1996). Cinematernity: Film, motherhood, genre. Princeton, NJ: Princeton University Press.10.1515/9781400851591[CrossRef]

Furedi, F. (2001). Paranoid parenting: Abandon your Anxieties and be a good parent. London: Allen Lane.

Gleiberman, O. (1991, July 19). Problem Child 2. Retrieved from http://www.ew.com/article/1991/07/19/problem-child-2

Guthmann, E. (1996, November 22). Film review - Arnie doesn't ring any comedy bells/Hokey holiday film doesn't quite 'Jingle'. Retrieved from http://www.sfgate.com/movies/article/FILM-

REVIEW-Arnie-Doesn-t-Ring-Any-Comedy-2958581.php

Hamad, H. (2014). Postfeminism and paternity in contemporary US film: Framing fatherhood. New York, NY: Routledge. 
Hays, S. (1996). The cultural contradictions of motherhood. New Haven, CT: Yale University Press.

Hillard, D. (1993, November 28). Review: 'Mrs. Doubtfire'. Retrieved

from http://variety.com/1993/film/reviews/mrs-doubtfire-2-1200434086/

Hinson, H. (1990, November 16). Home Alone. Retrieved

from http://www.washingtonpost.com/wp-

srv/style/longterm/movies/videos/homealonepghinson a0a9b9.htm

Hinson, H. (1991a, December 11). Hook. Retrieved from http://www.washingtonpost.com/wpsrv/style/longterm/movies/videos/hookpghinson a0a725.htm

Hinson, H. (1991b, July 5). Problem Child 2 (PG-13). Retrieved

from http://www.washingtonpost.com/wp-

srv/style/longterm/movies/videos/problemchild2pg13hinson a0a6c7.htm

Kapur, J. (2005). Coining for capital: Movies, marketing, and the transformation of childhood. New Brunswick, NJ: Rutgers University Press.

Keys, M. (2016). Lost footage: Heartbreaking "Mrs. Doubtfire" deleted scenes. Retrieved from https://www.youtube.com/watch?v=-8Y-uV2wJyM

Kincheloe, J. L. (1998). The new childhood: Home alone as a way of life.

In H. Jenkins (Ed.), The Children's culture reader (pp. 159-177). New York: New York University Press.

Kinder, M. (1991). Playing with power in movies, television, and video games: From Muppet Babies to Teenage Mutant Ninja Turtles. Berkeley: University of California Press.

Klinger, B. (1994). Melodrama and meaning: History, culture, and the films of Douglas Sirk. Bloomington: Indiana University Press.

Kramer, P. (1998). Would you take your child to see this film? The cultural and social work of the family-adventure movie. In M. Smith \& S. Neale (Eds.), Contemporary Hollywood

cinema (pp. 294-311). London: Routledge.

Leach, P. (1994). Children first: What our society must do - and is not doing - for our children today. London: Michael Joseph.

Lee, E. (2014). Introduction. In J. Bristow, E. Lee, C. Faircloth, \& J. Macvarish (Eds.), Parenting culture studies (pp. 1-22). Basingstoke: Palgrave

Macmillan.10.1057/9781137304612[CrossRef]

Levy, E. (1996, November 30). Review: 'Jingle All the Way'. Retrieved

from http://variety.com/1996/film/reviews/jingle-all-the-way-2-1117437028/

Leydon, J. (1996, August 5). Review: 'Matilda'. Retrieved

from http://variety.com/1996/film/reviews/matilda-2-1200446502/

Leydon, J. (1998, July 27). Review: 'The Parent Trap'. Retrieved

from http://variety.com/1998/film/reviews/the-parent-trap-3-1200454277/ 
Marilyn Beck, S. J. S. (1996, December 5). John Hughes has new kid for new 'Home Alone'. Manila standard. Retrieved

from https://news.google.com/newspapers?nid=1370\&dat=19961205\&id=4p4VAAAAIBAJ\&sjid= zgoEAAAAIBAJ \&pg=6146,737721\&hl=en

Maslin, J. (1990). Review/Film; Holiday black comedy for modern children. Retrieved from http://www.nytimes.com/movie/review?res=9C0CE6D8143DF935A25752C1A966958260

Maslin, J. (1992). Review/Film; Alone again: Holiday mischief in manhattan. Retrieved from http://www.nytimes.com/movie/review?res=9E0CEED71030F933A15752C1A964958260

Pickert, K. (2012). The man who remade motherhood. Retrieved from http://time.com/606/theman-who-remade-motherhood/

Sears, W., Sears, M., Sears, R., \& Sears, J. (2003). The baby book: Everything you need to know about your baby - from birth to age two (2nd ed.). Boston, MA: Little, Brown and Company.

Seiter, E. (1993). Sold separately: Children and parents in consumer culture. New Brunswick, NJ: Rutgers University Press.

Silberling, B. (2008) Casper DVD commentary. UK: Universal Pictures.

Stein, R. (1998, July 29). Family fixer-upper/“Parent Trap” gets a coat of sugar in entertainment remake. Retrieved from http://www.sfgate.com/movies/article/Family-Fixer-Upper-Parent-Trapgets-a-coat-of-2999456.php

Sutherland, A., \& Thompson, B. (2003). Kidfluence: The marketer's guide to understanding and reaching generation Y-kids, tweens, and teens. New York, NY: McGraw-Hill.

Warner, J. (2006). Perfect madness: Motherhood in the age of anxiety. London: Vermillon.

Williams, T. (1996). Hearths of darkness: The family in the American horror

film. London: Associated University Presses. 